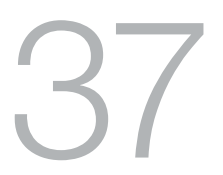

\title{
The Parliamentary Joint Committee on Intelligence and Security: A Point of Increasing Influence in Australian Counter- Terrorism Law Reform?
}

\author{
Dominique Dalla-Pozza
}

\section{Introduction}

On 12 November 2015, the House of Representatives debated the Australian Citizenship Amendment (Allegiance to Australia) Bill 2015 (Cth). The signature reforms in the Bill (enacted into law that December) are mechanisms for dual citizens to have their citizenship cease if they are involved with terrorist activity. ${ }^{2}$ The debate was the first to take place after the Parliamentary Joint Committee on Intelligence and Security

1 Lecturer in Law, The Australian National University. I acknowledge Lachlan Forrester for his research assistance, and The Australian National University College of Law for financial assistance supporting this research.

2 Supplementary Explanatory Memorandum, Australian Citizenship Amendment (Allegiance to Australia) Bill 2015 (Cth), 2-3. 
(PJCIS) had handed down its report scrutinising the Bill, ${ }^{3}$ and after the government had issued its response to the report. ${ }^{4}$ During the debate, Labor MP Michael Danby observed:

The evolution of this legislation ... shows the value of the committee system and the increasing influence of the PJCIS ... Committees might be seen as too slow for the 24/7 news cycle and the Twitterati, but the result is a pragmatic solution that is best for the Australian people ... and it shows that we parliamentarians are doing our job. ${ }^{5}$

In this chapter I examine the claim that PJCIS is wielding 'increasing influence' in the counter-terrorism law reform process. Analysing this claim is relevant to those interested in reform of Australia's counterterrorism law framework. If we can identify a particular point in the lawmaking process which is influential, then those interested in shaping the Australian counter-terrorism law framework can focus their efforts on it.

I summarise the extent of PJCIS involvement in 'pre-enactment scrutiny' of the alterations to the Australian counter-terrorism law framework that the Australian Parliament has passed since mid-2014. In this context, pre-enactment scrutiny refers to the processes by which a parliamentary committee examines a Bill before it is enacted into law by the whole parliament. The pre-enactment scrutiny inquiries I am interested in are those where a committee takes evidence from the public (through written submissions or hearings).

I also examine the extent to which the government has accepted recommendations made by the PJCIS. I accept that the question of how to assess the influence of parliamentary committees is evolving. ${ }^{6}$ Nevertheless, the evidence of the past two years suggests that the PJCIS is capable of making recommendations that require the government to

3 PJCIS, 'Committee Recommends Passage of the Citizenship Bill' (Media Alert, 4 September 2015), www.aph.gov.au/DocumentStore.ashx?id=a178407a-96fd-4400-9781-ecafc142443f.

4 Peter Dutton, Minister for Immigration and George Brandis, Attorney-General, 'Government Responds to Report on the Australian Citizenship Amendment (Allegiance to Australia) Bill 2015' (Joint Media Release, 10 November 2015), www.minister.border.gov.au/peterdutton/2015/Pages/ response-citizenship-amendment-bill.aspx.

5 Commonwealth, Parliamentary Debates, House of Representatives, 12 November 2015, 13119 (emphasis added).

6 David Monk, 'A Framework for Evaluating the Performance of Committees in Westminster Parliaments' (2010) 16 Journal of Legislative Studies 1, 2-5. 
adjust the law reform proposals they have put to parliament. ${ }^{7}$ Together, these points suggest that the PJCIS now represents a key locus where changes to a counter-terrorism legislative proposal could be advocated and might actually occur.

\section{The Extent of PJCIS Pre-enactment Scrutiny of Counter-Terrorism Law Proposals}

The PJCIS is the latest parliamentary committee to have oversight over ASIO. ${ }^{8}$ The committee was 're-established' in its current form at the end of 2005. The Intelligence Service Act 2001 (Cth) stipulates that the PJCIS is to consist of six members of the House of Representatives and five Senators.' The Act also requires that a 'majority of the Committee's members must be Government members. ${ }^{10}$ The committee has indicated that a 'significant portion of the committee's time during 2014-15 was focussed on examining national security legislation introduced by the Government'. ${ }^{11}$

The PJCIS has conducted pre-enactment scrutiny on six of the major pieces of counter-terrorism legislation introduced between 2014 and 2016. ${ }^{12}$ At the time of writing, five of the six pieces of legislation have been enacted. Each inquiry was initiated by the Attorney-General referring the relevant Bill to the PJCIS. ${ }^{13}$ This indicates that the government accepted that this form of parliamentary scrutiny was to be part of the law-reform process. It is important to remember that this type of parliamentary scrutiny is

7 David Monk, 'Committee Inquiries in the Australian Parliament and Their Influence on Government: Government Acceptance of Recommendations as a Measure of Parliamentary Performance' (2012) 18 The Journal of Legislative Studies 143-44.

8 Parliament of Australia, History of the Intelligence and Security Committee, www.aph.gov.au/ Parliamentary_Business/Committees/Joint/Intelligence_and_Security/History_of_the_Intelligence_ and_Security_Committee.

$9 \quad$ Intelligence Services Act 2001 (Cth) s 28(2).

10 Intelligence Services Act 2001 (Cth) s 28(3).

11 Parliamentary Joint Committee on Intelligence and Security, Parliament of Australia, Annual Report of Committee Activities 2014-15 (2015) 2.

12 These acts are the National Security Legislation Amendment Act (No 1) 2014 (Cth); the CounterTerrorism Legislation Amendment (Foreign Fighters) Act 2014 (Cth); the Counter-Terrorism Legislation Amendment Act (No 1) 2014 (Cth); the Telecommunications (Interception and Access) Amendment (Data Retention) Act 2015 (Cth) (the 'Data Retention Act'); the Australian Citizenship Amendment (Allegiance to Australia) Act 2015 (Cth); and the Counter-Terrorism Legislation Amendment Bill (No 1) 2015 (Cth).

13 Annual Report, above n 11, 5-8 and PJCIS, Parliament of Australia, Advisory Report on the Counter-Terrorism Legislation Amendment Bill (No 1) 2015 (2016) 1. 
not a compulsory feature of the law reform process. ${ }^{14}$ The involvement of these types of committees is important, because they provide one structured opportunity for the public, and non-government experts, to provide their opinions about Bills directly to parliamentarians. ${ }^{15}$ It also affords parliamentarians the ability to question the departments and agencies which designed the legislation, and that would be responsible for implementing it. ${ }^{16}$

Acknowledging that the government allowed the PJCIS to scrutinise the Bills does not mean that the committee scrutiny process was perfect. One flaw Appleby identifies is that the PJCIS was sometimes required to complete its pre-enactment scrutiny work on a very strict timeframe. ${ }^{17}$ On one occasion, the committee pointedly noted that 'it would have been preferable if more time had been available for the inquiry'. ${ }^{18}$ I concur that the time constraints placed on committee review were problematic. They made it more difficult for the committee 'to comprehend, question, test [the legislation and] to seek public and expert opinion' ${ }^{19}$ to assist them in providing as comprehensive review of the Bills as possible. However, not all of the inquiries of the PJCIS over this period were conducted so quickly. For example, the PJCIS inquiry into the Data Retention Act 2015 was allowed just under two months to take submissions (albeit over the summer holiday period of December to January). The overall time provided to the committee to complete its report was just over three months. ${ }^{20}$

14 The functions of the PJCIS do not mandate the type of pre-enactment Bill scrutiny conducted in this period. See Annual Report, above n 11, 19-21.

15 Dominique Dalla-Pozza, 'Promoting Deliberative Debate? The Submissions and Oral Evidence Provided to Australian Parliamentary Committees in the Creation of Counter-Terrorism Laws' (2008) 23 Australasian Parliamentary Review 39, 56. See also Richard Grant, 'Can We Account for Parliamentary Committees? A Survey of Committee Secretaries' (Parliamentary Studies Paper No 9, Parliamentary Studies Centre, 2009) 6, 8.

16 PJCIS, Parliament of Australia, Advisory Report on the Counter-Terrorism Legislation Amendment Bill (No 1) 2014 (2014), 11, 13: the Committee recorded evidence received from the Australian Federal Police and the Attorney-General's Department about the proposed changes in that Bill.

17 Gabrielle Appleby, 'The 2014 Counter-Terrorism Reforms in Review' (2015) Public Law Review 4, 4-7.

18 PJCIS, Parliament of Australia, Advisory Report on the Counter-Terrorism Legislation Amendment (Foreign Fighters) Bill 2014 (2014) 3.

19 Appleby, above n 17, 4 .

20 See PJCIS, Advisory Report into the Telecommunications (Interception and Access) Amendment (Data Retention) Bill 2014 (2015), 2, 4. 
Despite these problems, the fact remains that the PJCIS was the parliamentary committee most often charged with holding public inquiries examining proposed changes to Australian counter-terrorism law during this period. During 2014-16, only one of the six major counter-terrorism Bills was also referred to a Senate Legislation or References Committee for a separate pre-enactment scrutiny inquiry. ${ }^{21}$ That Bill, the CounterTerrorism Legislation Amendment (Foreign Fighters) Bill, was referred to the Senate Legal and Constitutional Affairs Legislation Committee (SLCALC). However, the SLCALC declined to accept submissions or to call witnesses because the PJCIS was already conducting an inquiry into the Bill. ${ }^{22}$ There are two ways to interpret this. The first is to be concerned about the exclusion of the Senate Committee. The decision of the SLCALC not to hold a public inquiry angered some members of the cross-bench because it meant that they were unable to be members of any committee conducting full pre-enactment scrutiny. ${ }^{23}$ This is because all members of the PJCIS were members of the major parties. ${ }^{24}$ Nevertheless, the SLCALC's deference to the PJCIS can also be interpreted as another indicium of the growing pre-eminence of the PJCIS in the sphere of counter-terrorism law reform. If these trends continue, the PJCIS will be the committee most likely to examine any future substantial proposals for change to the Australian counter-terrorism law framework.

\section{Recommendations and 'Strike Rate'}

Another key piece of information pointing to the PJCIS playing a crucial role in the Australian counter-terrorism law reform process is the extent to which the government accepted its recommendations. In discussing its pre-enactment scrutiny during the 2014-15 financial year, the committee commented that " $[\mathrm{a}]$ cross the four Bills reviewed during the reporting period, the committee made 109 recommendations. All of these recommendations were accepted and resulted in 63 amendments to the Bills before the Parliament'. ${ }^{25}$

21 Although in their report into the Data Retention Act the PJCIS acknowledged that the Senate Legal and Constitutional References Committee was examining broader issues relating to altering the Telecommunications (Interception and Access) Act 1979 (Cth) as a whole. See 'Advisory Report into the Data Retention Bill', above n 20, 3.

22 Senate Legal and Constitutional Affairs Legislation Committee, Parliament of Australia, Counter-Terrorism Legislation Amendment (Foreign Fighters) Bill 2014 (2014) 1.

23 For the views of the Australian Greens, see ibid. 6. See also Appleby, above n 17, 5-6 and 10.

24 Foreign Fighters Bill 2014, above n 22, 6.

25 Annual Report, above n 11, 3 (emphasis added). 
Some political scientists refer to this way of assessing influence as assessing a committee's 'strike rate'. The term 'strike rate' means 'the percentage of ... [committee] recommendations accepted and implemented by government'. ${ }^{26}$ Law reform scholars may be more interested in the extent to which committee recommendations result in concrete amendments to legislation as an indicium of committee influence. By either version of this measure, at least by its own account, the PJCIS has been remarkably influential.

Examining a 2014 PJCIS report on the Counter-Terrorism Legislation Amendment Bill (No 1) 2014 ('2014 CTLA Bill') provides an example of a recommendation from the PJCIS being the acknowledged catalyst for an alteration to the government's proposed amendments to Australia's counter-terrorism laws. The 2014 CTLA Bill proposed amendments to provisions governing when the Australian Federal Police (AFP) can request control orders. Prior to the enactment of the 2014 CTLA Bill, the control order provisions allowed an 'issuing court' to impose an order allowing certain 'conditions' to be placed on 'a person' for the purpose of 'protecting the public from a terrorist act'. ${ }^{27}$ The AFP are responsible for applying to the issuing court for the order, but in most cases need to obtain the consent of the Attorney-General before doing so. ${ }^{28}$ The conditions that a control order can impose include preventing a person subject to the order from communicating with certain persons, or mandating that they 'wear a tracking device'. ${ }^{29}$

One proposed change in the 2014 CTLA Bill concerned the mechanism by which the AFP could apply for an 'urgent interim control order'. Prior to the late 2014 reforms, a senior AFP officer could apply directly to the issuing court for such an order in certain circumstances. However, the consent of the Attorney-General to the making of the application needed to be granted retrospectively - within four hours of the application being made. ${ }^{30}$ The 2014 CTLA Bill proposed to lengthen the amount of time the AFP had to obtain the Attorney-General's consent from four hours to twelve. The PJCIS noted that 'some inquiry participants' did not feel that

26 John Halligan, Robin Miller and John Power, Parliament in the Twenty-First Century (Melbourne University Press, 2007) 222.

27 Advisory Report on the Counter-Terrorism Legislation Amendment Bill (No 1) 2014, above n 16, 6.

28 Ibid. See also Criminal Code Act 1995 (Cth) s 104.2 (1).

29 Advisory Report on the Counter-Terrorism Legislation Amendment Bill (No 1) 2014, above n 16, 6. See also Criminal Code Act 1995 (Cth) 104.5(3)

30 Advisory Report on the Counter-Terrorism Legislation Amendment Bill (No 1) 2014, above n 16, 17. 
the 'increase in time' had been 'adequately justified'. ${ }^{31}$ The PJCIS agreed, and recommended that the AFP be required to obtain consent within eight hours of the AFP applying for the urgent order. The government accepted this recommendation, and the legislation as enacted reflects it. ${ }^{32}$ Indeed, in its response the government mentioned that this change 'reflects the view of the Committee and some witnesses, that 8 hours is sufficient'. ${ }^{33}$ The impression that the PJCIS's recommendations are persuasive is bolstered by the fact that the government publicly attributed the making of this amendment specifically to the committee's work. ${ }^{34}$

However, when compared to the overall control order scheme, this change is relatively minor. In its report into the 2014 CTLA Bill the PJCIS noted that 'several submitters' had 'in-principle objections to the existence of control orders'. ${ }^{35}$ The committee also noted in passing that another oversight body - the Independent National Security Legislation Monitor - had recommended that the control order powers be completely repealed..$^{36}$ Ultimately, the PJCIS concluded that it accepted the justification offered by the AFP that the control order powers were necessary. ${ }^{37}$ As such, it did not recommend the complete removal of control orders from Australian law. So at least part of the PJCIS's high success rate may be explained if the recommendations made did not require major changes to the shape and scope of the counter-terrorism law framework. Political scientists who have studied other parliamentary committees have recorded the view of one committee secretary that, to ensure their recommendations are influential, committees can avoid making 'courageous' recommendations. ${ }^{38}$ At present, it is unclear how farreaching the totality of the recommendations made by the PJCIS were. This is an area which would benefit from further academic work.

\footnotetext{
31 Ibid.

32 George Brandis, Attorney-General, 'Government Response to the Committee Report on the Counter-Terrorism Legislation Amendment Bill (No 1) 2014' (Media Release, 25 November 2014) 3, www.attorneygeneral.gov.au/Mediareleases/Documents/GovernmentResponseToCommitteeReportO nTheCounter-TerrorismLegislationAmendmentBillNo1-2014.pdf. See Criminal Code Act 1995 (Cth) s 104.10 .

33 Brandis, above n 32, 3.

34 Monk, 'Evaluating the Performance of Committees', above n 6, 8.

35 Advisory Report on the Counter-Terrorism Legislation Amendment Bill (No 1) 2014, above n 16, 9.

36 Ibid. 11.

37 Ibid. 21-22.

38 Halligan, Miller and Power, above n 26, 222-23.
} 
There are two further complications to consider when using committee recommendations to assess the extent of the PJCIS's influence on law reform. The first is the division amongst political scientists about whether using government responses to parliamentary committees is actually a useful way of assessing committee influence. ${ }^{39}$ Some argue it is too difficult to accurately quantify the impact of parliamentary committees in isolation, as the process by which policy is formulated contains 'too many players and interactions s. ${ }^{40}$ Others think that, while imperfect, the government response 'is the closest approximation ... available' of what the government thinks of a report. ${ }^{41}$

The second caveat concerns the PJCIS's blanket statement that 'all the recommendations were accepted'. Closer examination of the legislative history of the 2014 CTLA Bill demonstrates that not all 'acceptances' are complete. One proposed change in that Bill was to expand the grounds on which a control order could be issued. The changes proposed to expand these grounds to include 'prevent[ing] the provision of support for or the facilitation of a terrorist act' and also the 'provision of support for or the facilitation of the engagement in a hostile activity in a foreign country. ${ }^{42}$ The PJCIS recommended 'that, to the extent possible, the terms "supports" and "facilitates" [in these changes] ... be based on language in the existing Criminal Code' and the Bill and explanatory memorandum be altered 'to reflect this'. ${ }^{43}$ The PJCIS justified this by arguing the evidence it received 'raised concerns' that it was unclear what was meant by 'the provision of support for' or 'facilitation of a terrorist act'. ${ }^{44}$ In response, the government noted that it accepted this recommendation 'in principle'. It agreed to amend the explanatory memorandum but did not propose to alter the Bill. ${ }^{45}$

It is still technically correct to call this an acceptance of the committee's recommendation, but it was not a complete acceptance of it. ${ }^{46} \mathrm{~A}$ complete acceptance would have been for the Bill and the explanatory memorandum

39 See Monk, 'Government Acceptance', above n 7, 138-39. See also Ian Holland, 'Senate Committees and the Legislative Process' (Parliamentary Studies Paper, No 7, Parliamentary Studies Centre, 2009) 5-6.

40 Halligan, Miller and Power, above n 26, 222.

41 Monk, 'Evaluating the Performance of Committees', above n 6, 8.

42 Advisory Report on the Counter-Terrorism Legislation Amendment Bill (No 1) 2014, above n 16, 7.

43 Ibid. 24 (Recommendation 2).

44 Ibid. 14, 24.

45 Brandis, above $\mathrm{n} 32,2$.

46 See also Monk, 'Government Acceptance', above n 7, 144-45. 
to be amended. This suggests that the statement that 'all recommendations were accepted' needs to be carefully unpacked to examine the extent to which the legislation as eventually enacted actually reflects the PJCIS's recommendations.

\section{Conclusion}

To return to the question which opened this chapter: is the PJCIS garnering 'increasing influence' in the area of Australian counter-terrorism law reform? On the basis of the study presented here, the answer would be a qualified yes. The fact that the PJCIS has considered the major counterterrorism law proposals put before parliament over 2014-16 makes it clear this is now the 'committee of choice' to conduct pre-enactment scrutiny. Even if the committee was sometimes rushed, the government seems prepared to have PJCIS scrutiny become a routine element of its counter-terrorism law-making process. If this continues, it will allow the committee to continue to develop its experience and expertise in the issues underpinning counter-terrorism law reform.

The answer to the question is qualified because the recommendations made by the PJCIS are not always in fact translated into amendments which alter counter-terrorism Bills. While on the surface the PJCIS's strike rate seems impressive, the extent to which it reflects actual change to the law is a more complex question. Also worthy of further study is the extent to which the PJCIS recommendations go to the core of the way in which powers such as the control order regime operate. However, despite these qualifications, there are instances where the PJCIS's recommendations have caused changes to Australia's counter-terrorism laws.

That the PJCIS has been given an opportunity to scrutinise counterterrorism Bills, and that the government seems open to their recommendations, should be recognised. The committee appears to be developing into a key point of influence for those seeking to make the case for law reform of Australia's counter-terrorism law framework. Accordingly, for those seeking change, participating in a future PJCIS inquiry into a counter-terrorism law issue seems a promising place to begin. 
This text is taken from New Directions for Law in Australia: Essays in Contemporary Law Reform, edited by Ron Levy, Molly O’Brien, Simon Rice, Pauline Ridge and Margaret Thornton, published 2017 by ANU Press, The Australian National University, Canberra, Australia. 